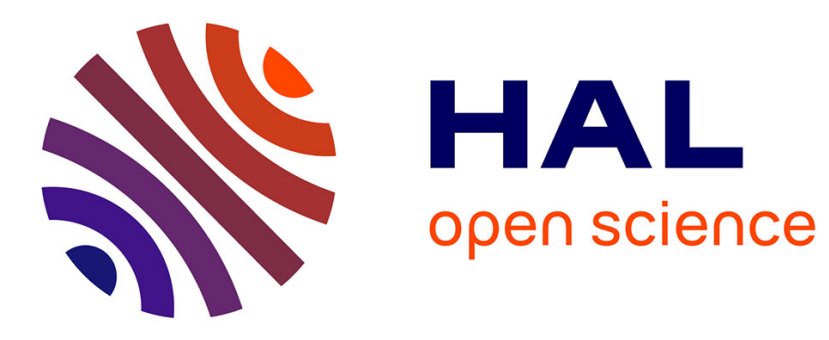

\title{
5-HT4 Receptors: Cloning and Expression of New Splice Variants
}

S. Claeysen, Patrick Faye, Michèle Sebben, Sylvie Taviaux, Joël Bockaert, Aline Dumuis

\section{> To cite this version:}

S. Claeysen, Patrick Faye, Michèle Sebben, Sylvie Taviaux, Joël Bockaert, et al.. 5-HT4 Receptors: Cloning and Expression of New Splice Variants. Annals of the New York Academy of Sciences, 1998, 861 (1), pp.49-56. 10.1111/j.1749-6632.1998.tb10172.x . hal-02489922

\section{HAL Id: hal-02489922 \\ https://hal.science/hal-02489922}

Submitted on 24 Feb 2020

HAL is a multi-disciplinary open access archive for the deposit and dissemination of scientific research documents, whether they are published or not. The documents may come from teaching and research institutions in France or abroad, or from public or private research centers.
L'archive ouverte pluridisciplinaire HAL, est destinée au dépôt et à la diffusion de documents scientifiques de niveau recherche, publiés ou non, émanant des établissements d'enseignement et de recherche français ou étrangers, des laboratoires publics ou privés. 


\title{
5-HT 4 Receptors: Cloning and Expression of New Splice Variants
}

Sylvie Claeysen ${ }^{1}$, Patrick Faye ${ }^{2}$, Michèle Sebben ${ }^{1}$, Sylvie Taviaux ${ }^{3}$, Joël Bockaert ${ }^{1}$, Aline Dumuis $^{1 *}$

${ }^{1}$ CNRS UPR 9023, Centre CNRS-INSERM de Pharmacologie-Endocrinologie (CCIPE), 141 rue de la Cardonille, 34094 Montpellier cedex 5, France

${ }^{2}$ Laboratoires Fournier (S.C.A.), 50 rue de Dijon, 21121 Dais cedex 05, France

${ }^{3}$ CRBM - CNRS, 1919 route de Mende, 34293 Montpellier cedex 5, France

*Corresponding author: Tel: +33.4.67.14.29.34; Fax: +33.4.67.54.24.32;

E-mail address: dumuis@ccipe.montp.inserm.fr

\begin{abstract}
On the basis of differences in the potencies and intrinsic activity of 5- $\mathrm{HT}_{4}$ receptor agonists in different biological models it has been suggested that there is heterogeneity among 5-HT4 receptors. Here, we report the molecular cloning of several 5- $\mathrm{HT}_{4}$ receptor splice variants in mouse, rat, and human brain. Our data suggest that the differences in efficacy of 5-HT 4 ligands on $5-\mathrm{HT}_{4}$ receptor-mediated responses in several tissues is due to differences in coupling efficiency rather than to the presence of different $5-\mathrm{HT}_{4}$ receptor isoforms.
\end{abstract}


Heterogeneity among 5- $\mathrm{HT}_{4}$ receptors has been suggested on the basis of differences in the potencies and intrinsic activity of 5- $\mathrm{HT}_{4}$ receptor agonists in different biological models. It has been proposed that these differences may be due to the existence of distinct 5- $\mathrm{HT}_{4}$ receptor subtypes. ${ }^{1,2}$ Although it has been proposed that the existence of $5-\mathrm{HT}_{4}$ receptor splice variants $\mathrm{s}^{3,4}$ might explain some tissular pharmacological differences, no clear data have yet been provided.

In this study, we report the molecular cloning of several other $5-\mathrm{HT}_{4}$ receptor splice variants in mouse, rat, and human brain. We present data suggesting that the difference in efficacy of 5-HT 4 ligands on 5- $\mathrm{HT}_{4}$ receptor-mediated responses in several tissues was not due to the presence of different $5-\mathrm{HT}_{4}$ receptor isoforms but was due rather to their coupling efficiency.

\section{CLONING OF TWO NEW SPLICE VARIANTS OF MOUSE 5-HT 4 RECEPTOR: m5-HT $_{4(c)}$ AND $_{(d)}$}

We have recently cloned the mouse $5-\mathrm{HT}_{4 \mathrm{~L}}\left(\right.$ or $\left.\mathrm{m}^{5}-\mathrm{HT}_{4(\mathrm{~b})}\right)$ receptor ${ }^{5}$ and found that the two isoforms L (or (b)) and S (or (a)) of the receptor are expressed whatever the structure of the brain studied. This observation, which was confirmed by Vilaro et al., ${ }^{6}$ prompted us to clone the short isoform of the $\mathrm{m}^{-}-\mathrm{HT}_{4}$ receptor. From whole brain RNA preparation, we isolated the full-length cDNA of the $\mathrm{m}^{-\mathrm{HT}_{4(\mathrm{a})}}$ receptor, corresponding to a deduced sequence of 387 amino acids. The nucleotide and peptide sequences were $94 \%$ and $96 \%$ identical to those of the r5$\mathrm{HT}_{4(\mathrm{a})}$, respectively. ${ }^{3} \mathrm{We}$ also cloned two splice variants of the $\mathrm{m} 5-\mathrm{HT}_{4}$ receptor that we named $\mathrm{m}^{-}-\mathrm{HT}_{4(\mathrm{c})}$ and $\mathrm{m}^{5}-\mathrm{HT}_{4(\mathrm{~d})}$ according to the NC-IUPHAR recommendation ${ }^{7}$ (Fig. 1a). Figure $1 \mathrm{~b}$ shows the three cDNA fragments obtained by PCR amplification of the C-terminal part of the

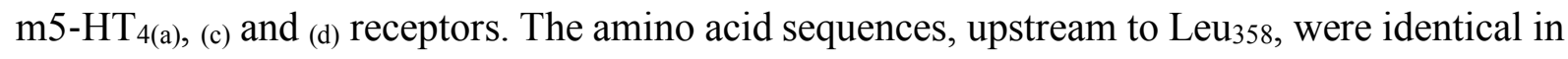

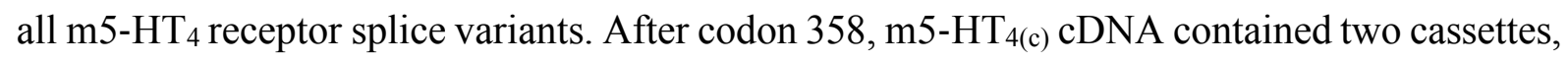
whereas m5-HT 4 (d) cDNA contained only the second one (Fig. 1a). The C-terminal nucleotide sequence of $\mathrm{m} 5-\mathrm{HT}_{4}$ (a) $\mathrm{cDNA}$ followed those cassettes. An in-frame stop codon appeared in the

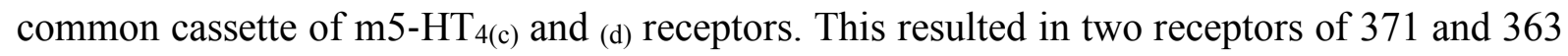
amino acids, respectively.

A priori, none of the differences in sequences observed between the four $\mathrm{m}_{5}-\mathrm{HT}_{4}$ receptor isoforms seem to be apt to lead to different pharmacological responses. Indeed, comparing the binding affinity constants for a series of agonists or antagonists or the affinity constants for stimulating adenylyl cyclase activity, when expressing in COS-7 cells, a significant correlation $(\mathrm{r}>0.95)$ was found between the four $\mathrm{m}_{5}-\mathrm{HT}_{4}$ isoforms. 


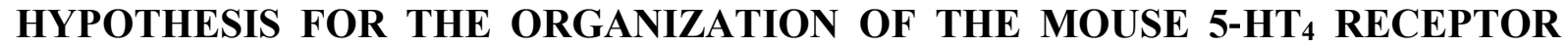 GENE}

For the mouse gene, we can imagine an organization with at least 5 exons, as described in Figure 1c. A first exon may contain the common 5' part of the four receptors 5-HT4(a) to (d). The first inserted cassette which appears in the m5-HT4(c) receptor and the second one, shared

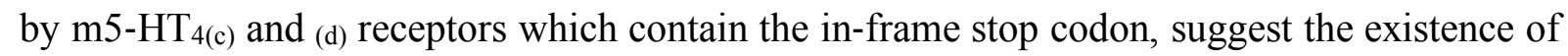
two additional and separate exonic cassettes (exon 2 and 3, on Fig. 1c). A fourth exon may correspond to the $\mathrm{C}$-terminal part of the $\mathrm{m} 5-\mathrm{HT}_{4}$ (a) receptor, which is also found in the splice variants (c) and (d) as non-coding sequence. The C-terminal part of the $\mathrm{m}_{5}-\mathrm{HT}_{4(\mathrm{~b})}$ receptor could be in a fifth exonic sequence. We cannot exclude that the $\mathrm{N}$-terminal common sequence is composed of more than one exon. Indeed, a splice variant presenting an extended second extracellular loop in the porcine $5-\mathrm{HT}_{4}$ receptor has been found. ${ }^{4}$ To confirm this hypothesis, we have to analyze the exon-intron organization on the $5-\mathrm{HT}_{4}$ receptor gene as recently done for the $5-\mathrm{HT}_{7}$ gene $^{8}$ which presents four splice variants differing also in the C-termini by alternative splicing.

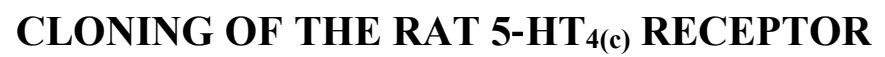

We also cloned the r5-HT4(c) receptor from rat brain (Fig. 1a). The nucleotide and peptide sequences of which were also $94 \%$ and $96 \%$ identical to those of the $\mathrm{m}^{2}-\mathrm{HT}_{4(\mathrm{c})}$ receptor, respectively. The receptor was 371 residues long, identical in length to $\mathrm{m}_{5}-\mathrm{HT}_{4(\mathrm{c})}$, and had only one amino acid change in the C-terminal part after the splicing site (Fig. 1d).

\section{CLONING OF TWO SPLICE VARIANTS OF HUMAN 5-HT 4 RECEPTOR: h5-HT4(b)} AND (e)

We isolated the cDNA of three human receptors: the h5- $\mathrm{HT}_{4(\mathrm{a})}$ receptor from the brain and the atrium, ${ }^{9}$ the $\mathrm{h} 5-\mathrm{HT}_{4(\mathrm{~b})}$ receptor and a novel splice variant $\mathrm{h} 5-\mathrm{HT}_{4}(\mathrm{e})$ receptor from the brain. The peptide sequences of the $\mathrm{h} 5-\mathrm{HT}_{4(\mathrm{~b})}$ was $92 \%$ identical to those of the $\mathrm{r} 5-\mathrm{HT}_{4(\mathrm{~b})}$ receptor, but one punctual insertion (an additional cytosine after position 1154) occurring in the last 50 nucleotides of the $\mathrm{h} 5-\mathrm{HT}_{4} \mathrm{cDNA}$ sequence induces a frameshift and the apparition of a stop codon leading to a form shorter by 18 residues (Fig. 1a). Therefore, the h5-HT4(b) receptor was 388 residues long (Fig. 1d). This receptor recently cloned by another group, ${ }^{10}$ confirmed the occurrence of the additional cytosine by partial sequencing of human and rat genomic DNA. In contrast to the published sequence, $\underline{3}$ they surprisingly found the same insertion in the rat 
genomic DNA; we therefore checked our sequence of the $\mathrm{m}_{5}-\mathrm{HT}_{4(\mathrm{~b})}$ receptor. $\underline{5}$ The additional cytosine was also present, but a compression occurring in this part of the sequence had made us initially find a cytosine doublet instead of a triplet really present in the mouse sequence.

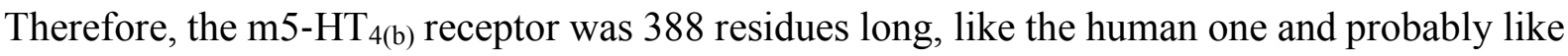
the one of the rat. The second human receptor we cloned, the h5- $\mathrm{HT}_{4}(\mathrm{e})$ receptor, presents the insertion of a cassette at the putative splicing site as seen in the $\mathrm{m}$ and $\mathrm{r} 5-\mathrm{HT}_{4(\mathrm{c})}$ receptors. This cassette led to a receptor of 378 residues, because of the presence of an in-frame stop codon (Fig. 1a). The species differences are probably due to altered intron-exon organization similar to the one described $5-\mathrm{HT}_{7}$ receptor gene. ${ }^{8}$

\section{SIGNIFICANT DIFFERENCES OBSERVED IN THE C-TERMINAL AMINO ACID SEQUENCES OF THE CLONED 5-HT 4 RECEPTOR SPLICE VARIANTS}

The alignment of the C-terminal amino acid sequences of the cloned 5- $\mathrm{HT}_{4}$ receptor isoforms of mouse, rat or human brain showed that the divergence in their sequences started after position $\mathrm{L}_{358}$. After these $\mathrm{L}_{358}$, all the receptor isoforms had their own specific sequence and length (Fig. 1d). Preliminary experiments indicated that $\mathrm{r} 5-\mathrm{HT}_{4(\mathrm{~b})}$ receptor (long form) desensitized more rapidly than the short form $5-\mathrm{HT}_{4(\mathrm{a})} \cdot{ }^{11}$ Indeed we have reported in a precedent study that a rapid and homologous desensitization of 5- $\mathrm{HT}_{4}$ receptors occur in mouse colliculi neurons. ${ }^{12}$ This type of desensitization is classically triggered via phosphorylation of the receptors by specific G-protein coupled receptor kinases called GRKs. ${ }^{13}$ The consensus sequences recognized by GRKs in GPCRs, could be $\mathrm{S}$ and $\mathrm{T}$ residues downstream of an acidic doublet such as DE, ED or EE in the C-terminal end of GPCRs. ${ }^{14}$ The r, m, and h5-HT 4 splice variants revealed that they shared the DE (331-332) doublet. This was the only acidic doublet present in all the $5-\mathrm{HT}_{4}$ receptor isoforms after the cysteine 328 , putative palmitoylation site (Fig. 1d). It remains to be demonstrated if there are differences in the mechanism and rate of desensitization between the 5- $\mathrm{HT}_{4}$ splice variants. It will also necessary to determine which of the serines and threonines downstream this acidic doublet are indeed phosphorylated during desensitization.

It was interesting to note that the new cloned splice variants $\mathrm{m}^{5}-\mathrm{HT}_{4(\mathrm{c})}$ and $(\mathrm{d}), \mathrm{r}^{5}-\mathrm{HT}_{4}(\mathrm{c})$ and $\mathrm{h} 5-\mathrm{HT}_{4(\mathrm{e})}$ receptor shared the same four carboxy-terminal residues: PVPV (Fig. 1d). Recently, a variety of proteins with PDZ domains has been identified that interacts with receptors containing a valine at the carboxyl-terminal end. ${ }^{15}$ These proteins with PDZ domains seem to act as molecular organizers that cluster receptors in the plasma membrane or mediate 
direct protein-protein interaction essential for intracellular signaling. The specificity of the interaction seems to be determined by the adjacent three or four residues before the carboxyterminal residue. This PVPV sequence present in the four $5-\mathrm{HT}_{4}$ receptor splice variants has also been shown at the carboxy-terminal end of receptor tyrosine kinase. ${ }^{16}$ The structural feature of the sequence PVPV forming several angles, owing to the presence of two prolines, could determine the specificity of the protein-protein interaction.

\section{CHROMOSOMAL LOCALIZATION}

We used the recently cloned $\mathrm{h} 5-\mathrm{HT}_{4}(\mathrm{a})$ receptor cDNA to map the chromosomal localization. ${ }^{9,17}$ By using fluorescence in situ hybridization, we showed that this gene mapped at the locus 5q31-q33, which was syntenic to the region carrying three other receptors, positively coupled to adenylyl cyclase, the dopamine $D_{1}$ receptor, and the $\beta_{1}$-and the $\beta_{2}$ adrenergic receptors. ${ }^{18,19}$ The general sequence homologies between these receptors was relatively low $(28.4,29$ and $27.8 \%$, respectively) but high if one considers the important domains interacting with Gs such as the end of the third intracellular loop. Both $\beta$-adrenergic ( $\beta_{1}$ - and the $\beta_{2}$ ) and 5-HT4 receptor stimulation increased atrial cAMP levels, activated cAMPdependent protein kinase A (PKA) and, ultimately, increased heart rate and contractile force (only in atrial cells for $5-\mathrm{HT}_{4}$ receptor). However, these receptors differently contributed to the cAMP-dependent positive inotropic response of human atrial cells, which can also vary during pathology. It has been reported that both $\beta_{2}$-adrenergic receptor and $5-\mathrm{HT}_{4}$ receptor responsiveness vary during pathology in human atrial tissues from heart failure patients treated chronically with $\beta_{1}$-adrenoreceptor antagonists. ${ }^{2}$ The same chromosomal localization might explain the cross-talk expression observed between $\beta_{2}$-adrenoreceptors and 5 - $\mathrm{HT}_{4}$ receptors, which has been previously interpreted as a consequence of increased receptor density. Cells from patients with various forms of $5 \mathrm{q}$ syndrome ${ }^{20}$ should provide useful material for exploring the effects of such genetic abnormalities on $5-\mathrm{HT}_{4}$ receptor expression.

COMPARISON BETWEEN THE PHARMACOLOGICAL PROPERTIES OF 5-HT 4 ANTAGONISTS ON 5-HT 4 RECEPTORS IN COLLICULI NEURONS AND TRANSFECTED COS-7 CELLS: EVIDENCE FOR EXISTENCE OF INVERSE AGONISTS

In COS-7 cells, we observed that all $5-\mathrm{HT}_{4}$ receptor isoforms were able to activate adenylyl cyclase in the absence of agonists, even when expressed at physiological density (25- 
$200 \mathrm{fmol} / \mathrm{mg}$ protein). This spontaneous activity was termed constitutive activity in the pioneer work of Costa and Hertz and Cotecchia et al. ${ }^{21,22}$ It is now accepted that receptors exist in equilibrium between two conformations, an inactive state $\mathrm{R}$ and an active state $\mathrm{R}^{*}$. Spontaneous isomerization occurs between these two forms and only the $\mathrm{R}^{*}$ conformation can interact efficiently with $\mathrm{G}$ proteins. The constitutive activity of the native $5-\mathrm{HT}_{4}$ receptor transfected in COS-7 cells ( $98 \pm 16 \mathrm{fmol} / \mathrm{mg}$ protein) was confirmed by the discovery of three inverse agonists of 5- $\mathrm{HT}_{4}$ receptors-GR 113808, GR 125487, and SB 207266-all of which inhibited the basal cAMP formation. SB 207266 had a higher efficacy than the others (Fig. 2c, d). In contrast, they were not able to inhibit basal cAMP formation in colliculi neurons expressing similar amounts of $5-\mathrm{HT}_{4}$ receptors $(60 \pm 23 \mathrm{fmol} / \mathrm{mg}$ protein). A comparison in the ability of each isoform to induce constitutive activity at the same receptor density has to be analyzed. It seems that less $\mathrm{R}^{*}$ was present in neurons than in COS-7 cells for the same total $\mathrm{R}+\mathrm{R}^{*}$ concentration.

During the last ten years, the $5-\mathrm{HT}_{4}$ receptor has been defined essentially on the basis of transductional and pharmacological criteria in several models including mouse colliculi neurons, guinea pig ileum and colon, rat esophagus, and human heart. 1 Generally, similar pharmacological properties were found in the different models used, despite a few differences in potency and activity (partial or total agonist or antagonist) of some compounds. However, in a recent report Leung et al. ${ }^{23}$ observed that several novel selective 5-HT 4 compounds showed an opposing pattern of activity when tested in guinea-pig colon or rat esophagus, which is difficult to explain by a difference in coupling efficiency. Here, we show that highly potent and selective 5-HT 4 ligands, described as potent neutral antagonists in colliculi neurons (Fig. 2a, c), were partial agonists, neutral agonists or inverse agonists when tested in COS-7 cells expressing one of the 5-HT 4 receptor isoforms (Fig. 2b, d). GR 113808, GR 125487 and SB 207266 inhibited the constitutive activity of the receptor and behaved as inverse agonists (Fig. 2b). In contrast, RS 100235, described as the most potent 5-HT 4 antagonist in colliculi neurons and in other models, ${ }^{24}$ was a neutral antagonist in COS-7 cells; it inhibited only 5-HT-induced cAMP production (Fig. 2a, b). It was also able to competitively inhibit the inverse agonist effect of GR 125487 on the 5-HT 4 receptor transiently expressed in COS-7 or LLC-PK1 cells (not shown). Furthermore, other potent $5-\mathrm{HT}_{4}$ antagonists on $5-\mathrm{HT}_{4}$ receptor in colliculi neurons: RS 39604, SB 204070, ML 10302, RS 23597 and DAU 6285 behaved as partial agonists (Fig. $2 \mathrm{c}, \mathrm{d})$. None of the benzoate compounds tested, which are potent $5-\mathrm{HT}_{4}$ receptor antagonists in colliculi neurons, ${ }^{1,25}$ displayed any inverse agonistic activity. 
These results are a further illustration of differences in pharmacology that could be found when the same receptors are expressed in different cellular contexts. These differences in pharmacological property requests caution when designing the nature of novel 5- $\mathrm{HT}_{4}$ drugs. Their agonistic or antagonistic effects may depend on the coupling efficiency between the $5-\mathrm{HT}_{4}$ receptor and $\mathrm{G}$ protein in the biological model selected.

\section{CONCLUSION}

The number of splice variants of the 5- $\mathrm{HT}_{4}$ receptor is on the increase. Although, Gerald et al. described only two splice variants $\left(\mathrm{r} 5-\mathrm{HT}_{4(\mathrm{a})}\right.$ and $\left.(\mathrm{b})\right),{ }^{3} \mathrm{Ullmer}$ et al. have also described the possible existence of 5- $\mathrm{HT}_{4}$ receptor splice variants in the second extracellular loop. ${ }^{4}$ Here, we found two novel splice variants in mouse (m5-HT 4 (c) and $\left.{ }_{(\mathrm{d})}\right)$ and human (h5-HT4(b) and (e) and one in rat $\left(\mathrm{r}^{2}-\mathrm{HT}_{4(\mathrm{c})}\right)$. The new splice variants, like the first two, varied in their $\mathrm{C}$-terminal domain, after $\mathrm{L}_{358}$. Alignment of the $\mathrm{C}$-terminal of all these splice variants indicated that they probably derived from a gene having a complex organization.

We found that $5-\mathrm{HT}_{4}$ receptors transfected in COS-7 cells at low density gave a constitutive activity which was inhibited by compounds thought to be neutral antagonists, behaving as inverse agonists. In colliculi neurons, we observed no evidence for a constitutive activity of $5-\mathrm{HT}_{4}$ receptors. 


\section{REFERENCES}

1 Eglen, R. M. \& S. S. Hedge. 1996. 5-hydroxytryptamine (5-HT4) receptors: Physiology, pharmacology and therapeutic potential. Exp. Opin. Invest. Drugs 5: 373- 388.

2 Kaumann, A. J. 1994. Do human atrial 5-HT4 receptors mediate arrhythmias? Trends Pharmacol. Sci. 15: 451- 455.

3 Gerald, C. et al. 1995. The 5-HT4 receptor: Molecular cloning and pharmacological characterization of two splice variants. EMBO J. 14: 2806- 2815.

4 Ullmer, C. et al. 1995. Expression of serotonin receptor mRNAs in blood vessels. FEBS Lett. 370: $215-221$.

5 Claeysen, S. et al. 1996. Cloning, expression and pharmacology of the mouse 5-HT4L receptor. FEBS Lett. 398: 19- 25.

6 Vilaro, M. T. et al. 1996. Localization of 5-HT4 receptor mRNA in rat brain by in situ hybridization histochemistry. Mol. Brain Res. 43: 356- 360.

7 Hoyer, D. \& G. Martin. 1997. 5-HT Receptor classification and nomenclature: Towards a harmonization with human genome. Neuropharmacology 36: 419-428.

8 Heidmann, D. E. A. et al. 1997. Four 5-hydroxytryptamine 7 (5-HT 7$)$ receptor isoforms in human and rat produced by alternative splicing: Species differences due to altered intronexon organisation. J. Neurochem. 68: 1372-1381.

9 Claeysen, S. et al. 1997. Cloning and expression of human 5-HT 4 S receptors. Effect of receptor density on their coupling to adenylyl cyclase. Neuroreport 8: 3189-3196.

10 VanDen Wyngaert, I. et al. 1997. Cloning and expression of a human serotonin 5-HT4 receptor cDNA. J. Neurochem. 69: 1810- 1819.

11 Adham, N. et al. 1995. Differential sensitivity of the short and long rat 5-HT4 receptor subtypes to desensitization. In 25th Annual Meeting of the Society For Neuroscience, November 11-16, 1995. 1-773. San Diego, California.

12 Ansanay, H. et al. 1992. Characterization of homologous 5- $\mathrm{HT}_{4}$ receptor desensitization in colliculi neurons. Mol. Pharmacol. 42: 808-816.

13 Premont, R. T., J. Inglese \& R. J. Lefkowitz. 1995. Protein kinases that phosphorylate activated G protein-coupled receptors. FASEB J. 9: 175- 182.

14 Fredericks, Z. L., J. A. Pitcher \& R. J. Lefkowitz. 1996. Identification of the G proteincoupled receptor kinase phosphorylation sites in the human $\beta_{2}$-adrenergic receptor. J. Biol. Chem. 271: 13796- 13803.

15 Saras, J. \& C. H. Heldin. 1996. PDZ domains bind carboxy-terminal sequences of target proteins. Trends Pharmacol. Sci. 21: 455- 458.

16 Wicks, I. P. et al. 1992. Molecular cloning of $H E K$, the gene encoding a receptor tyrosine kinase expressed by human lymphoid tumor cell lines. Proc. Natl. Acad. Sci. USA 89: 16111615 . 
17 Claeysen, S. et al. 1997. Assignment of 5-Hydroxytryptamine Receptor (HTR4) to human chromosome 5 band(s) q31-33 by in situ hybridization. Cytogenet. Cell Genet. 78: 133-134.

18 Grandy, D. K. et al. 1990. A human D1 dopamine receptor gene is located on chromosome 5 at q35.1 and identifies an EcoRI RFLP. Am. J. Hum. Genet. 47: 828-834.

19 Yang-Feng, T. L. et al. 1990. Chromosomal organization of adrenergic receptor genes. Proc. Natl. Acad. Sci. USA 87: 1516-1520.

20 Bartsch-Sandhoff, M. \& R. Liersch. 1977. Partial duplication 5q syndrome: Phenotypic similarity in two sisters with identical karyotype, partial duplication 5p33-5qter and partial deficiency 8p23-pter. Ann. Genet. 20: 281- 284.

21 Costa, T. \& A. Hertz. 1989. Antagonists with negative intrinsic activity at $\delta$ opioid receptors coupled to GTP-binding proteins. Proc. Natl. Acad. Sci. USA 86: 7321- 7325.

22 Cotecchia, S. et al. 1990. Regions of the a1-adrenergic receptor involved in coupling to phosphatidylinositol hydrolysis and enhanced sensitivity of biological function. Proc. Natl. Acad. Sci. USA 87: 2896- 2900.

23 Leung, E. et al. 1996. Comparison of 5-HT4 receptors in guinea-pig colon and rat oesophagus: Effects of novel agonists and antagonists. Naunyn-Schmiedeberg's Arch. Pharmacol. 354: 145-156.

24 Bockaert, J., L. Fagni \& A. Dumuis. 1997. 5-HT 4 Receptors: An update. In Handbook of Experimental Pharmacology: Serotoninergic Neurons and 5-HT Receptors in the CNS. H. G. Baumgarten \& M. Göthert, Eds. 129: 439-465. Springer-Verlag. Berlin, Heidelberg, New York.

25 Eglen, R. M. et al. 1995. Central 5-HT4 receptors. Trends Pharmacol. Sci. 16: 391- 398. 


\section{FIGURE LEGENDS}

\section{Figure 1}

Differences in the C-termini of the mouse, rat and human 5- $\mathrm{HT}_{4}$ splice variants. (a) Schematic representation of the nucleotide cassettes composing the receptors. *, position of the stop codon. (b) PCR amplification of cDNA fragments corresponding to the C-terminal part of the mouse splice variants (a), (c) and (d). The PCR was performed on retro-transcribed poly(a)+ RNA from whole mouse brain using the upper primer: 5' CCAAAGCAGCCAAGACT 3' (International Patent WO94/14957, Sequence 1, position 864-880) and the lower primer: 5' TAGtAaCCTGTtCATGCAGACACA 3' (Patent, Sequence 1, position 1302-1325). The fragments are separated by electrophoresis on a $2.5 \%$ agarose gel. (c) Putative organization of the intron-exon in the mouse $5-\mathrm{HT}_{4}$ receptor gene. Schematic representation of the splicing events producing mRNA for the four different isoforms. *, position of the different in-frame stop codons. (d) Carboxy-terminal amino acid sequences of the cloned 5- $\mathrm{HT}_{4}$ receptor splice variants indicated in a.

\section{Figure 2}

Comparison between the pharmacological properties of 5- $\mathrm{HT}_{4}$ antagonists on $5-\mathrm{HT}_{4}$ receptors in colliculi neurons and transfected COS-7 cells. Evidence for existence of inverse agonists. Panels (a) and (c) represent the activity of well-known 5-HT4 antagonists on 5-HT-stimulated cAMP formation in colliculi neurons. Neuronal cells were exposed to increasing concentrations of each antagonist in the presence of $1 \mu \mathrm{M} 5$-HT. The results are expressed as a percentage of residual stimulation relative to the stimulatory action of $1 \mu \mathrm{M}$ of 5 -HT taken as $100 \%$. Panels (b) and(d) represent the activity of the same drugs on the h5-HT4(a) receptor transiently transfected in COS-7 cells expressing $98 \pm 16 \mathrm{fmol} / \mathrm{mg}$ protein. cAMP production was measured during $30 \mathrm{~min}$ and expressed as a percent of control (mock transfected Cos-7 cells). 
(a)

$\mathrm{m}_{5}-\mathrm{HT}_{4}$

(b)

(c)

(d)

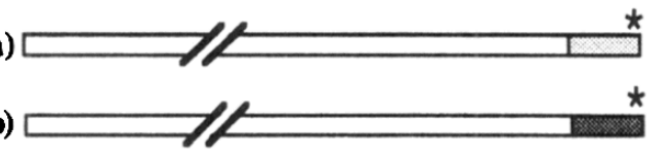

(a)
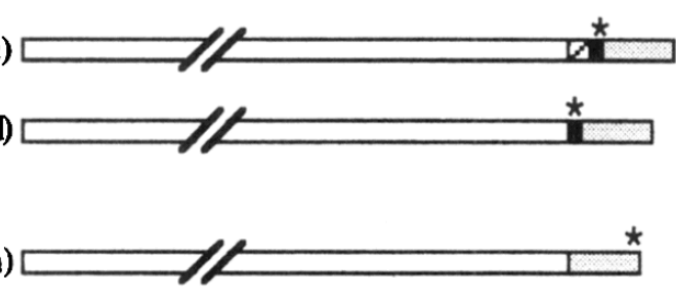

$\mathrm{r5}^{-\mathrm{HT}_{4}}$

(b)

(c)

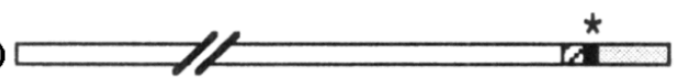

(b)

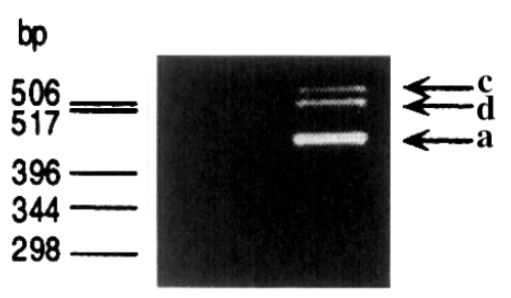

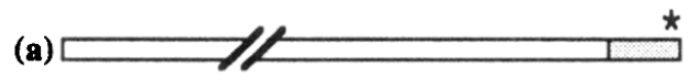

h5-HT 4

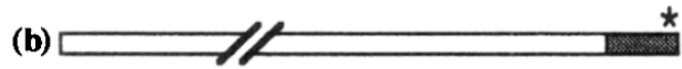

(e)

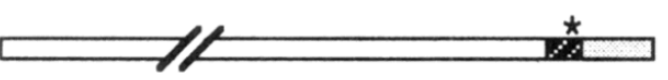

()

(b)

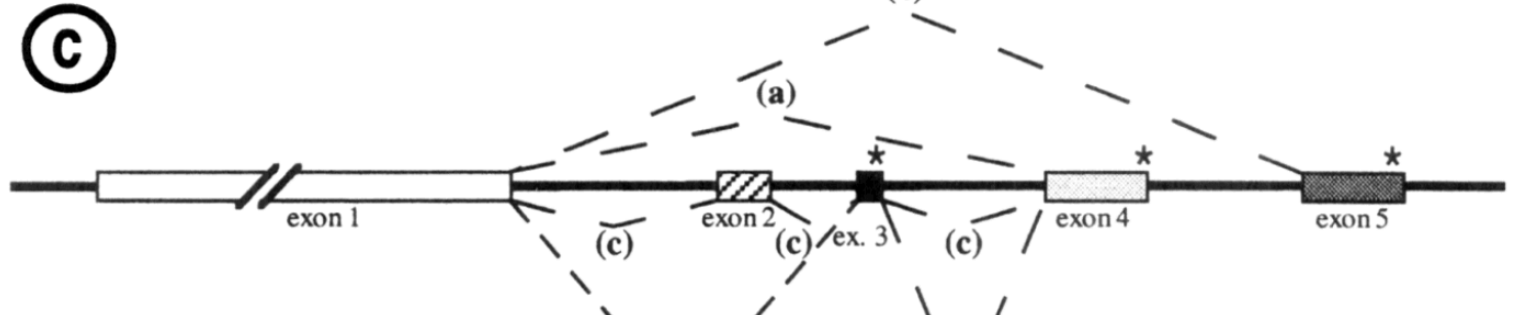

(d)
(a) DRYTVLhGhHQLeKLPIHndeslescF $\mathbf{3 8 7}$
(b) LRDAVCGGQWESRCHLTATSPLVAAQPSDT $\mathbf{3 8 8}$
(c) LSF PLLFRNR PVPV 371
(d) LRPVPV 363

$\mathrm{m5}^{-\mathrm{HT}_{4}}$

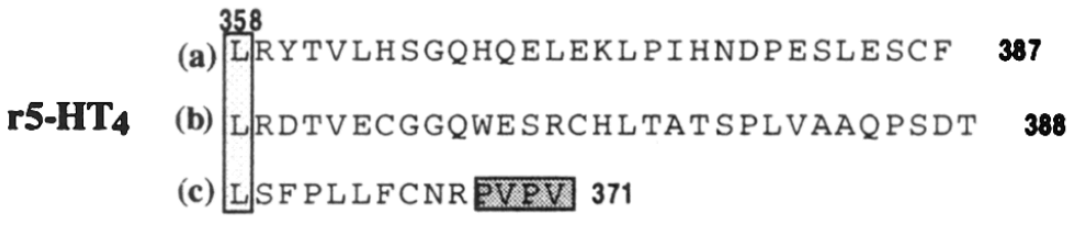

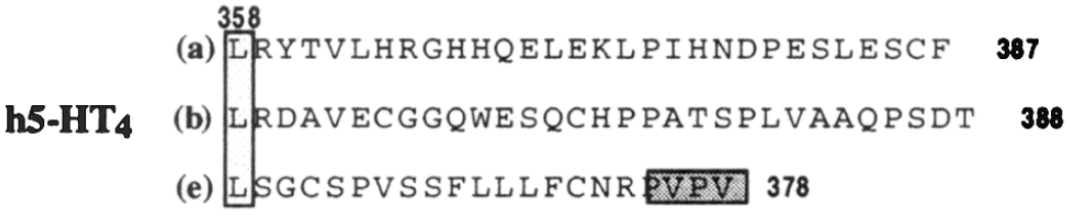

Figure 1 
$5 \mathrm{HT}_{4} \mathrm{R}$
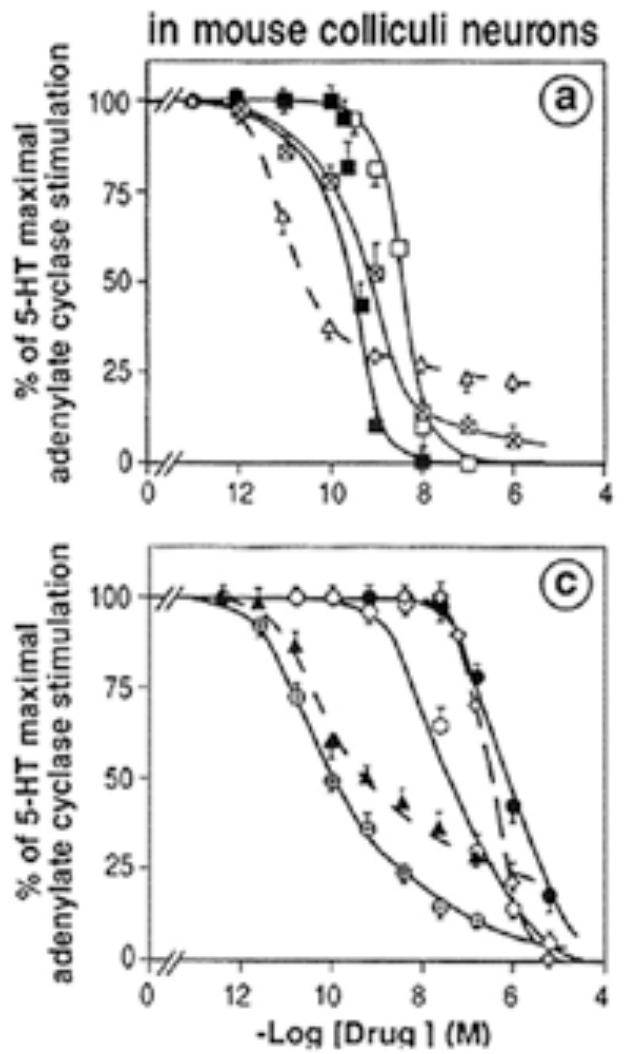

h5HT4(a)

in Cos-7 cells
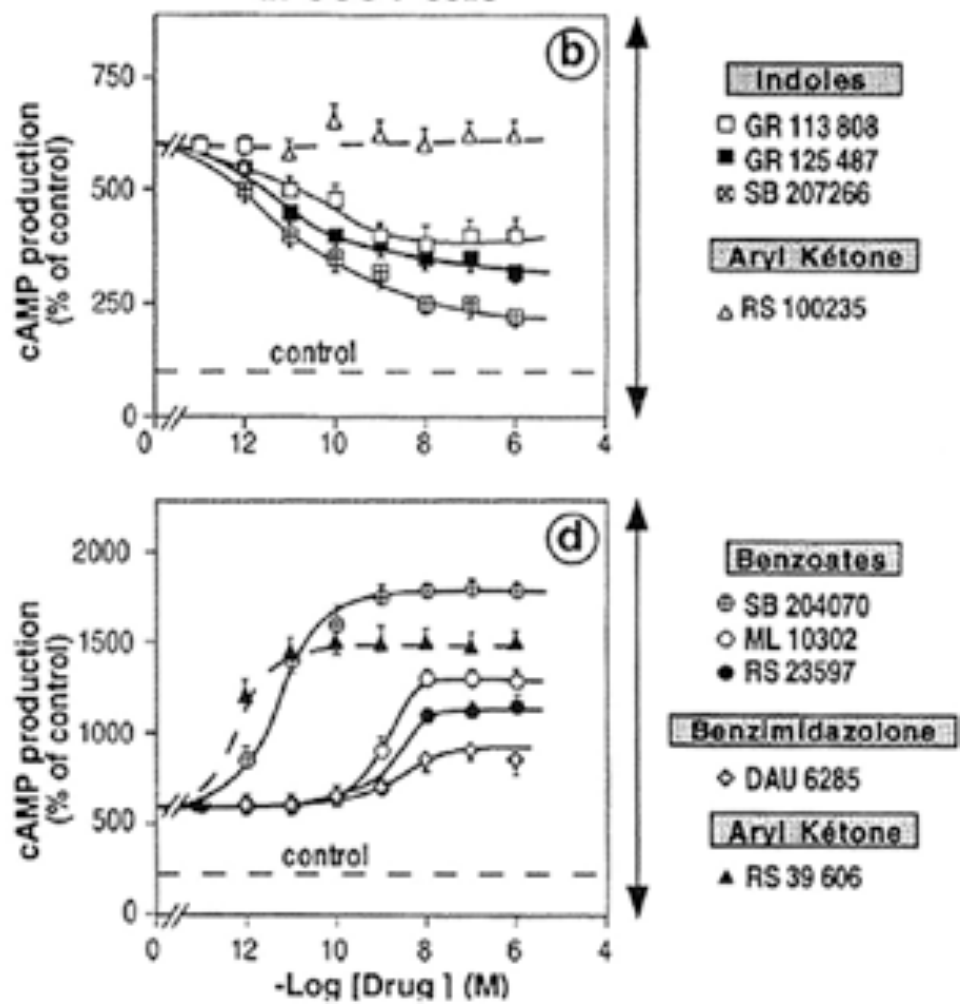

Figure 2 